\title{
Climate Change Adaptation Policy in Malaysia: Issues for Agricultural Sector
}

\author{
Md. Mahmudul Alam * \\ Institute for Environment and Development (LESTARI) \\ National University of Malaysia (UKM) \\ E-mail: rony000@gmail.com \\ Chamhuri Siwar \\ Emeritus Professor \\ Institute for Environment and Development (LESTARI) \\ Universiti Kebangsaan Malaysia \\ E-mail: csiwar@ukm.my \\ Basri Talib \\ Associate Professor \\ Faculty of Economics and Business \\ Universiti Kebangsaan Malaysia (UKM) \\ E-mail: basri@ukm.my

\section{Mazlin Mokhtar} \\ Professor and Director \\ Institute for Environment and Development (LESTARI) \\ Universiti Kebangsaan Malaysia \\ E-mail: mazlin@ukm.my
}

\section{Mohd Ekhwan bin Toriman}

Associate Professor

School of Social, Development \& Environmental Studies (FSSK)

Universiti Kebangsaan Malaysia (UKM)

E-mail: ikhwan@ukm.my

*corresponding author

\section{Citation Reference:}

Alam, M.M., Siwar, C., Talib, B., Mokhtar, M., and Mohd Ekhwan, T. 2012. Climate Change Adaptation Policy in Malaysia: Issues for Agricultural Sector, African Journal of Agricultural Research, Vol. 7(9), pp. 1368-1373, DOI: 10.5897/AJARX11.030. Available at < https://academicjournals.org/journal/AJAR/article-abstract/D6B4EC436577 >

This is a pre-publication copy.

The published article is copyrighted by the publisher of the journal. 


\title{
Climate Change Adaptation Policy in Malaysia: Issues for Agricultural Sector
}

\begin{abstract}
Malaysia is one of the highly vulnerable countries due to climatic changes. Here the changes in climate factors cause adverse impacts on agricultural sustainability and relevant livelihood sustainability. To adapt to these changes a prudent adaptation policy is very important. Several countries follow different adaptation policy based on their localized socioeconomic and geographical status. While defining its adaptation policy, Malaysia also needs to consider several crucial factors. This study discusses issues relevant to the farmers' adaptation to climate change in Malaysia and also provides few recommendations that will help policy makers to prepare the agricultural adaptation policy for climate change.
\end{abstract}

Key words: Agricultural sustainability; Sustainable livelihood; Climate change; Adaptation; Mitigation; Policy; Malaysia

\section{Introduction}

The factors of climate are changing all over the world that adversely affects different social groups differently. The agriculture is fully dependent on the factors of climate as a consequence climate change has adverse impacts on agriculture and agriculture relevant stakeholders. Among all the stakeholders, the farmer community is the most affected and risk group due to their full dependency on agriculture.

Currently, Malaysia ranks as the 26th largest greenhouse gas emitter in the world with a population of about 27 million, and it appears likely to move up the list quickly due to the growth rate of emissions. Here, due to high greenhouse gas emissions, the temperature is projected to rise by $0.3-4.5^{\circ} \mathrm{C}$, which will cause the sea level to rise by about $95 \mathrm{~cm}$ over a hundred-year period. The changes in rainfall may fluctuate from about $-30 \%$ to $+30 \%$. This change will reduce crop yield and become prone to drought in many areas so that cultivation of some crops such as rubber, oil palm, and cocoa will not be possible (NRS 2001). The projection shows that the maximum monthly precipitation will increases up to $51 \%$ over Pahang, Kelantan and Terengganu, while minimum precipitation will decrease between $32 \%$ to $61 \%$ for all over Peninsular Malaysia. Consequently, annual rainfall will increase up to $10 \%$ in Kelantan, Terengganu, Pahang and North West Coast, and decrease up to 5\% in Selangor and Johor (NAHRIM 2006). This variation of climate factors will cause the agricultural system to be vulnerable in Malaysia.

The average temperature in the rice growing areas in Malaysia is about $26^{\circ} \mathrm{C}$. Under the current climatic change scenario, temperatures above $25^{\circ} \mathrm{C}$ may cause decline in grain mass by $4.4 \%$ per $1{ }^{\circ} \mathrm{C}$ rise in temperature (Tashiro and Wardlaw 1989) and grain yield may decline as much as $9.6-10.0 \%$ per $1{ }^{\circ} \mathrm{C}$ rise (Baker and Allen 1993). Singh et al. (1996) mentioned that the actual farm yields of rice in Malaysia vary from 3-5 tons per hectare, where potential yield is 7.2 tons. They also mentioned that there is a decline of rice yield between $4.6 \%-6.1 \%$ per $1{ }^{\circ} \mathrm{C}$ temperature increase under the present $\mathrm{CO}_{2}$ level, but a doubling of $\mathrm{CO}_{2}$ concentration (from present level 340ppm to 680ppm) may offset the detrimental effect of $4^{\circ} \mathrm{C}$ temperature increase on rice production in Malaysia. In a recent study, it has been found that a $1 \%$ increase in temperature will lead to $3.44 \%$ decrease in current paddy 
yield, and $0.03 \%$ decrease in paddy yield in the following season. A $1 \%$ increase in rainfall will lead to $0.12 \%$ decrease in current paddy yield, and $0.21 \%$ decrease of paddy yield in the following season (Alam et al. 2010c).

Tisdell (1996) mentioned that rainfall variability increases the level of environmental stress that affects the capability of the system to maintain productivity. It is projected that any changes, both positive and negative, more than only $0.4 \%$ by 2020 will cause the yield of paddy production in Malaysia to fall (NRS 2001). Alam et al. (2011a) mentioned that total yearly rainfall in Malaysia is increasing but its monthly variation is too high. Therefore, the effect of lower rainfall is almost possible to check through proper irrigation system, but the opposite phenomenon of over rainfall for any particular time, especially at the end of the crop cycle or at the maturity period, causes serious damages of crops, which is absolutely uncontrollable now.

Moreover, the climatic factors affect, directly or indirectly, the social and economic sustainability of the farmers. Climate changes causes crop damages, low productivity and high production cost that leads to losses of farmers' income, poverty level increases, and seasonal unemployment rate increase (Alam et al. 2011b; Siwar et al. 2009). In Malaysia, the most possible vulnerable states in terms of poverty are Sabah (23\%), Terengganu (15.4\%), Kelantan (10.6\%), Sarawak (7.5\%), Kedah (7\%), Perlis $(6.3 \%)$ and Perak (4.9\%), where the projected temperature and rainfall changes are also very high (Ninth Malaysia Plan 2006, NAHRIM 2006).

Due to the climate change the agricultural sector in Malaysia is vulnerable in terms of economic aspects (Alam et al. 2011b), and the farming community is vulnerable in terms of socioeconomic aspects (Alam et al. 2010a). Thus, here, adaptation is very important for sustainability of agriculture and relevant livelihood.

\section{Importance of Adaptation}

As climate change is a continuous and long-term process, its effects and solutions are similarly a time and effort consuming process. Most of the warming during the next 30 years will be due to emissions that have already occurred. Over the longer term, the degree and pace of warming mainly depend on the current and near future emissions (Stern 2007).

In recent years, adaptation has gained prominence as an important response measure, especially for vulnerable countries, as it has become clear that some impacts are now unavoidable in the short to medium term. According to IPCC (2001), adaptation refers to "adjustments in ecological, social, or economic systems in response to actual or expected stimuli and their effects or impacts. This term refers to changes in processes, practices, and structures to moderate potential damages or to benefit from opportunities associated with climate change". It outlines a few basic principles: adaptation to short-term climate variability and extreme events for reducing vulnerability to long-term climate change; adaptation policy and measures assessed in a developmental context; adaptation occurs at different levels in society, including the local level; adaptation strategy and the process by which it is implemented are equally important. According to UNDP (2005), "A climate change adaptation strategy for a country refers to a general plan of action for addressing the impacts of climate change, including climate variability and extremes. It may include a mix of policies and measures, selected to meet the overarching objective of reducing the country's vulnerability." 
To adopt with climate change, conventionally, mitigation has received more attention than adaptation, both from a scientific and policy perspective. Mitigation is the main way to prevent future impacts of climate change, and it will reduce the cost of adaptation. Therefore, any delay in mitigation strategy to reduce emissions will increase the need and cost of adaptation, and increase the risk of global climate change. On the other hand, though adaptation is not a substitute of mitigation, there are arguments for adaptation to be considered as a response measure. Mitigation actions never stop a certain degree of climate change due to historical emissions and the inertia of the climate system (IPCC 2001). Moreover, mitigation effects may take several decades to manifest, where most adaptation activities take immediate effect. Adaptation reduces risks associated with current climate variability as well as addressing the risks associated with future climate changes, where mitigation only focuses on future risks. The measures of adaptation can be applied to a local scale or root level with the involvement of large number of stakeholders, where mitigation works in the decision making level. In the current world, climate factors are exogenous variables that are immitigable in a quick manner and as a consequence adaptation is the most appropriate way to cope with the system properly. It is therefore important to balance between measures against the causes of climate change and measures to cope with its adverse effects (Stern 2007; Pielke et al. 2007).

Adaptation strategies are crucial for vulnerable groups because failure to adapt could lead to "significant deprivation, social disruption and population displacement, and even morbidity and mortality" (Downing et al. 1997). The most critical problem is to identify the appropriate adaptation policies that favor the most vulnerable groups. Different approaches have been taken by different countries to adapt to climate changes. Nepal takes the approach of community based adaptation measures to weather related disasters, micro-finance mechanism through special insurance scheme to cope with increasing flash-flood, and adaptation through institutional arrangement. Mongolia takes the approach of policy framework for adaptation strategies for the Mongolian rangelands to climate change at multiple scales, and risk communication at multiple levels to build common awareness. India takes the approach of promoting integration of adaptation strategies into developmental policies by effectively communicating climate risks and adaptation measures. Philippines takes the approach of mainstreaming climate change adaptation in watershed management and upland farming. Bangladesh takes the approach of participatory climate risk assessment and development of local adaptation action plans, community-based practice to survive in changing ecosystem condition- permanent flood (water logging), and household level adaptation. Now it is very essential for the vulnerable countries to take relevant adaptation approaches and policies based on the sort of climate change problems, socioeconomic, and geographical characteristics.

The IPCC distinguishes several types of adaptation (IPCC 2001): Anticipatory/ Proactive Adaptation- that takes place before impacts of climate change are observed; Autonomous/ Spontaneous Adaptation- that does not constitute a conscious response to climatic stimuli but is triggered by ecological changes in natural systems and by market or welfare changes in human systems; Planned Adaptation- that is the result of a deliberate policy decision, based on an awareness that conditions have changed or are about to change and that action is required to return to, maintain, or achieve a desired state; Private Adaptation- that is initiated and implemented by individuals, households or private companies, usually related to the actor's rational self-interest; Public Adaptation- that is initiated and implemented by governments at all levels, usually directed at collective needs; 
and Reactive Adaptation- that takes place after impacts of climate change have been observed.

IPCC (2001) mentioned a few issues which refer to adaptation assessment as the "practice of identifying options to adapt to climate change and evaluating them in terms of criteria such as availability, benefits, costs, effectiveness, efficiency and feasibility". Policy makers also need to focus on the determinants of adaptation capacity that have been suggested by Yohe (2001): the range of available technological options for adaptation; the availability of resources and their distribution across the population; the structure of critical institutions, the derivative allocation of decision-making authority, and the decision criteria that would be employed; the stock of human capital, including education and personal security; the stock of social capital, including the definition of property rights; the system's access to risk-spreading processes, e.g., insurance; the ability of decision makers to manage information, the processes by which these decision-makers determine which information is credible and the credibility of the decision-makers, themselves, and the public's perceived attribution of the source of stress and the significance of exposure to its local manifestations. Therefore, while developing an approach to adaptation, Malaysia should carefully focus on several issues.

\section{Adaptation Policy}

Adaptation is too broad to attribute its costs clearly, because it needs to be undertaken at many levels, including at the household and community level, and many of these initiatives are self-funded (Stern 2007). Options for agricultural adaptation can be grouped as technological developments, government programs, farm production practices, and farm financial management (Smit and Skinner 2002). Thus, it has been suggested to prepare a planned and proactive adaptation strategy to secure sound functioning of the economic, social and environmental system (Alam et al. 2010e). Relevant specific policy recommendations are also proposed below for different stakeholders for better coping with the problem.

\section{Government's Policies, Challenges and Actions}

Government as the policy and law making authority has to play the most influential role to ensure adaptation at all levels. It is the main responsibility of the government to arrange enough supports to adopt farmers to climate change and try to make farmers self-sufficient rather than subsidy dependent.

Government bodies need to carefully define its subsidy supports and incentive programmes to influence farm-level production practices and financial management. Here, agricultural policies and investments need to be more strategic (Alam et al. 2011d). Furthermore, these policies need to be defined and ensure the compensation, minimum income protection, and insurance facility for the affected groups - individual farmers or farms.

Currently, the government has allocated a certain amount of land only for Malay farmers even though their productivity is lower than other ethnic groups (Alam et al. 2011c). It is also a threat for achieving self-sufficiency level of paddy production at the national level. At the same time, due to having high productivity of Chinese farmers, if government allots more land to Chinese farmers, it will create a social imbalance. Therefore, the government should initiate policies that aim to help Malay farmers boost their productivity through 
specific training or education programmes, awareness creation programmes or extra incentive programmes.

Production practices are important relative to current government policy. Government assigned the area only for paddy production. It has several implications. Farmers are not allowed to select crops of their own choice regardless of their tendency to produce own chosen crops (Alam et al. 2011d). Moreover, land degradation is high in this area due to mono crop production. Here, based on soil suitability, crop rotation and crop variety are needed to maintain land fertility and reduce the risk of climate change. Government has to ensure resource allocation properly with enough relevant infrastructural and informational supports. It also needs to develop programmes to control the influences of the usage of all types of fresh water resources and its reservation.

Other relevant factors, such as agricultural wage, land leasing system and rate, maximum farm size, etc. need much attention (Alam et al. 2011e). These factors are very important for sustainability of small farmers, poverty reduction and reduce income inequality (Alam et al. 2010d, 2011c). Government's attention to these factors will help increase overall productivity to gain self-sufficiency, or close to self-sufficiency, and to ensure food security (Alam et al. 2011f).

Government currently provides chemical fertilizers to farmers to increase productivity. Government policy should be environmentally friendly so that subsidy would be provided more on organic fertilizers than chemical fertilizers. Moreover, technological development should get high priority as it is proven to have positive impacts on paddy yield (Alam et al. 2010c). Government needs to spend more and also subsidize more on technological improvements to get more benefits in the future.

In the planning processes, policy makers need to take into account the barriers to adaptation including ecological, financial, institutional, and technological barriers, as well as information and cognitive hurdles. Other few important issues need to be focused upon, such as stakeholders may not be sufficiently informed about the needs and possible strategies of climate change (Eisenack and Kropp 2006; Eisenack, Tekken and Kropp 2007), farm level faces uncertain future which hinders the development process and poses an obstacle to the implementation of adaptations policy (Behringer et al. 2000; Brown et al. 2007), and the policy deals with different conflicting interest groups. Policy makers also need to understand the impact of climate change on changing socioeconomic conditions. Based on the socioeconomic patterns, different countries follow their own approaches to adaptation to climate change. Malaysia is in the process of determining its adaptation approach. It should carefully determine its adaptation policy based on climate change related potential socioeconomic vulnerability among different stakeholders at different levels. For example, farmers need more intensive health care supports from government with respect to climate change related disease, and they expect training, advices, and guidelines in regard to adaptation to climate change (Alam et al. 2011e). It also needs to consider climate change adaptation as risk management approach rather than trying to preserve/conserve present conditions. In a holistic plan, the climate change problems and its adaptation and mitigation need to be an integral part of the overall development program of Malaysia.

Moreover, government needs to be the main player in terms of coordination and collaboration among different government agencies and also external parties. Coordination among environmentalists, politicians, economists, and agricultural policy-makers is very 
essential to integrate issues of climate change into existing agricultural policies and development programmes.

Finally, to avoid future climate changes and to control pollutions and emissions, a proper mitigation policy is urgently required for Malaysia. There are innumerable uncertainties in current climate change projections. Moreover, these projections do not incorporate the complex socio-economic relationships in the model. Further, there is a chance that in future, the agricultural sector will also need to include mitigation policies due to the emission from commercial farming. Several programmes, such as the Clean Development Mechanism (CDM) to balance carbon emission, may be needed in future for both agriculture and wider development activities. Therefore, policymakers need to take flexible policy approaches to cope with increased uncertainty in the future.

\section{Farm Level Policies and Strategies}

To enable farmers adapt to climate change, initially it is very important to make them aware about future risk of climate change, especially climate change related socioeconomic vulnerabilities (Alam et al. 2010b, d). It will prepare them to deal with climate change and other socioeconomic stresses, and let them think about how to respond in adverse situations.

Secondly, the production practices of farms and individual farmers need to be kept up to date with the changes in climate factors. They should also take all precautions and be aware of the uncertainty of low rainfall and heavy rainfall. They must be careful in arranging proper water management, both in terms of irrigation facilities and quick water logout facilities (Alam et al. 2011g). Apart from that, they also need to understand the importance of proper timing and react quickly at the sight of upcoming rainfall events.

Thirdly, as the supply of irrigation water and changing crop cycle are emerging problems in the IADA area (Alam et al. 2011a), farmers should be informed about crop rotation, crop portfolio, and crop substitutions to address the environmental variations and economic risks associated with climate change. Moreover, they need to utilize land properly and change the location of crop production if possible, to cope with extreme cases. Further, they also need to develop efficient irrigation practices to address the moisture deficiencies and drought associated with climate change. Finally, they need to adapt to the changing duration of growing seasons and associated changes in climate factors.

Finally, the financial management of farms and farmers too need to be secured for a minimum of two seasons so that if crop is damaged in one season, they will be prepared and have the seeds for the next season; their ability to bear the cost of another crop production will guarantee their survival financially up to the collection of the new crops. Currently, heavy rainfall and storm is a very common phenomenon in the study area. For that reason, farmers, here, should take the initiative for crop sharing, forward rating, hedging, and insurance etc. Farmers also mentioned about the necessity of insurance facility, but no such option is currently available here. Moreover, they need to take income stabilization programmes, such as portfolio of investment, saving scheme, minimum income protection by government or insurance etc, to reduce the risk of income loss due to changing climate conditions and variability.

\section{Involvement of Other Stakeholders}


Mitigation of, or adaptation to, climate change is an issue that concerns all sectors and levels of everyday life; be it political, administrative or economic. To better cope, cooperation is necessary across countries, sectors and administrative levels. Relevant actors are needed to be aware of the benefits of cooperation to gain long-term benefits instead of focusing only on short-term and individual interests.

On the basis of several requirements of farmers, different new groups need to be involved to ensure that the required facilities are provided. Financial institutions need to be involved more to provide supports related to loan, insurance, saving schemes, hedging/future option etc. NGOs should also be involved more to provide supports related to training, health care, advices etc. In addition, it is important to involve researchers to share their findings on changes in climate factors and level of effects of the changes.

Moreover, technological adaptation is most important to deal with the problem in the long run. Development of technology is a boundless area. It can be developed in several possible ways. The highest efficient way of technological advancement is being able to solve the problem, such as China made an example of man-made precipitation as well as protect precipitation (MacLeod 2006). Until gaining such a complete advancement, there should be a few alternative options that will help to adapt to climate change in the following different ways:

- to solve the problem: controlling the pattern of rainfall, sunshine, moisture level

- to improve shielding resources: protect crops from excessive rainfall or sunshine, solve water logging problems

- to develop defensive approach: varieties of crops development, rainfall and temperature tolerant plants, find alternative crops, hybrids

- to find alternative approach: changing crop cycle, reduce the timing of crop cycle

- to provide information: weather forecast, early warning system, ensuring delivery of proper information to farm level

Finally, as climate change is not particularly related to any community, everyone needs to be informed about its impacts and they should also be encouraged to think about its possible adaptation approaches. Due to social interaction, the socioeconomic variables of any community have strong linkages, interactions and influences of other community, and for any national or common issue all social groups are interconnected and, more or less, affected. Therefore, everyone in the society needs to build up a mind set about the warming climate, and what needs to be done. At the same time, people, particularly those in the richer countries, need to explore the best ways to build low-carbon economies in spite of their luxurious and overconsumption patterns of lifestyle. That will help to curb the socioeconomic vulnerability of any particular groups in the society, and enable everyone in similar types of mentality to cope with the adverse effects of climate change.

\section{Conclusion}

Climate is changing all over the world, but the phase of changes and effects are different among areas and sectors. Due to climate change, the socioeconomic statuses of the farmers, the direct and most vulnerable group, are affected significantly. Climate changes causes crop damages, low productivity and high production cost that leads to losses of farmers' income, high poverty level, high inequality, and finally the reduction of farmers' active involvement 
in agriculture. Ownership criteria of cultivated land are changing because, due to less returns, small owners rent out land to the large farms. Uncertainty of climate change causes frequent sickness, diseases, and health hazard to the farmers. Moreover, off-farm wage rate is higher than the agricultural income so that farmers try to engage in agriculture on a part-time basis. Government makes rules to produce specific crops in particular area, but farmers' tendency is to shift crops due to the changes in agricultural profitability. As a result, the paddy producing area is continuously decreasing in the last few years.

Adaptation is very essential in the long run for agricultural and livelihood sustainability in Malaysia. Adaptation approaches need to be followed at individual farmer level, and policy level. Adaptation will be highly dependent on technology in the long-run and financial protection in the short-run. Government bodies too need to take preferable subsidy policy and ensure financial sustainability for the farmers.

\section{Reference}

Alam M.M., Siwar C., and Toriman M.E. (2010a) Socioeconomic Study of Climate Change: An Assessment of Agriculture and Livelihood Sustainability on Paddy Farming in Malaysia. LAP Lambert Academic, Saarbrucken.

Alam M.M., Siwar C., Murad M.W., Molla R.I., and Toriman M.E. (2010b) Socioeconomic Profile of Farmer in Malaysia: Study on Integrated Agricultural Development Area in North-West Selangor. Agricultural Economics and Rural Development 7(2):249-26. ftp://www.ipe.ro/RePEc/iag/iag_pdf/AERD1013_249-265.pdf Cited 05 Nov 2011

Alam M.M., Talib B., Siwar C., Toriman M.E. (2010c) The Impacts of Climate Change on Paddy Production in Malaysia: Case of Paddy Farming in North-West Selangor. Proceedings of the international conference of the 4th International MalaysiaThailand Conference on South Asian Studies. National University of Malaysia, Malaysia, Mar 25-26

Alam M.M., Siwar C., Molla R.I., Toriman M.E., and Talib B. (2010d) Socioeconomic Impacts of Climatic Change on Paddy Cultivation: An Empirical Investigation in Malaysia. Journal of Knowledge Globalization 3(2):71-84. http://journals.sfu.ca/jkg/index.php/journal/article/view/57/44 Cited 05 Nov 2011

Alam M.M., Siwar C., and Al-Amin A.Q. (2010e) Climate Change Adaptation Policy Guidelines for Agricultural Sector in Malaysia. Asian Journal of Environmental and Disaster Management 2(4):463- 469. DOI 10.3850/S1793924011000873 Cited 05 Nov 2011

Alam M.M., Toriman M.E., Siwar C., and Talib B. (2011a) Rainfall variation and changing pattern of agricultural cycle. American Journal of Environmental Science 7:82-89. DOI 10.3844/ajessp.2011.82.89 Cited 05 Nov 2011

Alam M.M., Siwar C., Molla R.I., Toriman M.E., and Talib B. (2011b) Climate Change and Vulnerability of Paddy Cultivation in North-West Selangor, Malaysia: A Survey of Farmers' Assessment. Voice of Academia 6(1):45-56.

Alam M.M., Siwar C., Talib B., and Toriman M.E. (2011c) An Empirical Study on the Relationships between the Socioeconomic Profile of Farmers and Paddy Productivity in North-West Selangor, Malaysia. Asia-Pacific Development Journal 18(1). http://www.unescap.org/pdd/publications/apdj-18-1/5-Alam-and-others.pdf Cited 05 Nov 2011

Alam M.M., Toriman M.E., Siwar C., Molla R.I., and Talib B. (2011d) The Impacts of Agricultural Supports for Climate Change Adaptation: Farm Level Assessment Study 
on Paddy Farmers. American Journal of Environmental Sciences 7(2): 178-182. DOI 10.3844/ajessp.2011.82.89 Cited 05 Nov 2011

Alam, M.M., Siwar C., Toriman M.E., Molla R.I., Talib B. (2011e) Climate Change Induced Adaptation by Paddy Farmers in Malaysia. Mitigation and Adaptation for Global Change, DOI: 10.1007/s11027-011-9319-5 Cited 05 Nov 2011

Alam, M.M., Siwar C., Murad M.W., Toriman M.E. (2011f) Impacts of Climate Change on Agriculture and Food Security Issues in Malaysia: An Empirical Study on Farm Level Assessment. World Applied Sciences Journal 14(3): 431-442. http://idosi.org/wasj/wasj14(3)11/12.pdf Cited 05 Nov 2011

Alam, M.M., Siwar, C., Molla, R.I., Talib, B., and Toriman M.E. (2011g) Paddy Farmers' Adaptation Practices to Climatic Vulnerability in Malaysia, Mitigation and Adaptation for Global Change, DOI: 10.1007/s11027-011-9333-7 Cited 05 Nov 2011

Baker JT, Allen JrLH (1993) Contrasting crop species responses to $\mathrm{CO}_{2}$ and temperature: rice, soybean and citrus. Vegetatio 104/105: 239-260. http://www.jstor.org/pss/20029749. Cited 05 Aug 2011

Behringer, J., Buerki, R. \& Fuhrer, J. (2000). Participatory integrated assessment of adaptation to climate change in Alpine tourism and mountain agriculture. Integrated Assessment 1: 331-338.

Brown, K., Few, R. \& Tompkins, E.L. (2007). Climate change and coastal management decisions: insights from Christchurch Bay, Coastal Management 35(2-3): 255-270.

Downing TE, Ringius L, Hulme M, Waughray D (1997). Adapting to climate change in Africa. Mitigation and Adaptation Strategies for Global Change, 2: 19-44. (online) http://www.africa-

adapt.net/aa/uploads/Resources/7b79b1db63dc45b6b2d24ac0c5171d62_Adapting\%2 0to\%20climate\%20change\%20in\%20Africa.pdf Cited 05 Nov 2011

Eisenack, K. \& Kropp, J. (2006). Regional stakeholder perceptions of climate change: Baltic case study screening, ASTRA document, Potsdam.

Eisenack, K., Tekken, V. \& Kropp, J. (2007). Stakeholder Perceptions of climate change in the Baltic Sea Region. Coastline Reports 8: 245-255.

IPCC (Intergovernmental Panel on Climate Change). (2001). Climate Change 2001: Impacts, Adaptation and Vulnerability. IPCC Third Assessment Report, Cambridge University Press: Cambridge, U.K.

MacLeod, C. (2006). China rolls out the big guns, aiming for a dry Olympics. USA Today, Jun 29. Available at < http://www.usatoday.com/news/world/2006-06-29-chinarain_x.htm> (Jun 25 2010).

NAHRIM (2006). Final Report: Study of the Impact of Climate Change on the hydrologic Regime and Water Resources of Peninsular Malaysia, National Hydraulic Research Institute of Malaysia (NAHRIM) and California Hydrologic Research Laboratory (CHRL), Malaysia. (online) http://www.nahrim.gov.my/download/pksa/RegHCM_PM_Report_9_21_06_Ex\%20v 1.pdf Cited 05 Nov 2011

Ninth Malaysia Plan (2006). Ninth Malaysia Plan 2006-2010. The Economic Planning Unit, Prime Minister's Department, Putrajaya, Malaysia. (online) http://www.parlimen.gov.my/news/eng-ucapan_rmk9.pdf Cited 05 Nov 2011

NRS (2001). National Response Strategies to Climate Change. Ministry of Science, Technology and the Environment, Malaysia. (online) http://gedung.nahrim.gov.my/wapi/mctweb.dll/getObject?MID=WATER\%20RESOU RCES\&Sn=2038 Cited 05 Nov 2011

Pielke, R., Prins, G., Rayner, S. \& Sarewitz, D. (2007). Lifting the taboo on adaptation. Nature 445(7128): 597-598. 
Singh, S., Amartalingam, R., Wan Harun, W.S. \& Islam, M.T. (1996). Simulated impact of climate change on rice production in Peninsular Malaysia. Proceeding of National Conference on Climate Change. pp. 41-49, UPM, Malaysia.

Siwar C, Alam MM, Murad MW, and Al-amin AQ (2009) A review of the linkages between climate change, agricultural sustainability and poverty in Malaysia. International Review of Business Research Papers 5(6):309-321. http://www.bizresearchpapers.com/23.\%20Siwar.pdf. Cited 05 Aug 2011

Smit, B. \& Skinner, M.W. (2002). Adaptation options in agriculture to climate change: a typology. Mitigation and Adaptation Strategies for Global Change 7: 85-114.

Stern, N. (2007). The Economics of Climate Change: The Stern Review. Cambridge University Press: Cambridge.

Tashiro T, Wardlaw IF (1989). A comparison of the effect of high temperature on grain development in wheat and rice. Annals of Botany, 64: 59-65. (online) http://aob.oxfordjournals.org/content/64/1/59.full.pdf Cited 05 Nov 2011

Tisdell C (1996). Economic indicators to assess the sustainability of conservation farming projects: An evaluation. Agriculture, Ecosystems and Environment, 57(2): 117-131. http://www.sciencedirect.com/science/article/pii/0167880996010171 Cited 05 Nov 2011

UNDP, (2005). Adaptation Policy Framework for Climate Change: Developing Policies Strategies and Measures. B. Lim and E. Spanger-Siegfred (eds.). Cambridge University Press: Cambridge, UK.

Yohe, G. \& Tol, R.S.J. (2001). Indicators for social and economic coping capacity: Moving toward a working definition of adaptive capacity. Global Environmental Change 12: $25-40$. 